doubt that The Odes of Solomon will stand out as the most important. "In a small and rather shabby Syriac MS. which he had purchased long before, and then laid aside, he found and gave to the world in rgro one of the most valuable monuments of the spiritual life of the early Church. In the definitive edition, in two superb quarto volumes, The Odes and Psalms of Solomon, reedited for the Governors of the John Rylands Library, by Rendel Harris and Alphonse Mingana (Manchester: at the University Press, I9r6-1920), we are provided inter alia with a bibliography of over nine pages, showing how widespread an interest has been created by this discovery. Honorary degrees have been showered upon him, and, if rumour speaks true, more are to come.

Much of his recent work, The Dioscuri in
Christian Legend, The Cult of the Heavenly Twins, Origin of the Cult of Dionysos, Origin of the Cult of Apollo, Origin of the Cult of Artemis, Origin of the Cult of Aphrodite, Origin of Apple Cults, take one into regions where $I$ at least am not able to follow him. But over all his work is seen the same profundity of recondite learning, the same fertility of imagination, the same attractiveness of presentation.

Yet the real man is greater than all his works. His secret is to be found, if at all, in other works, Memoranda Sacra (1892), Union with God (1895), The Guiding Fand of God (1905), The Sufferings and the Glory (1914). May this servant of God be long preserved among us to show that learning and piety can dwell together outside the priesthood of any church!

\title{
On the Eams of Bromtb in the Ministry.
}

\section{AN ADDRESS TO MINISTERS.}

\section{By Principal E. Griffith-Jones, D.D., The United College, Bradford.}

Horace Bushnell, in his fine address on Pulpit Talent, gives an account of eight or ten qualities in a man which are necessary for the attainment of eminence in the ministry of Jesus Christ. Among these there is : one which he calls the GrowthTalent, or the Talent for Improvability. He says what is very true, that there are men who never grow after they leave college. They grew up to a certain point, and there was an end of it. At school they excelled, and gave the highest promise in their first effort at preaching. But they were soon at their limit, and this limit they will never pass. They seem to have all the talents, and have them in full order, but somehow 'the law of increment' is wanting. Their capital is good enough, but it is invested so as to gather no per cent. of interest money; it is not cumulative. There is, he says, another kind of souls that mature more slowly and under a different law. 'Increment is their destiny. Their force makes force. What they gather seems to enlarge their very brain. Nobody thought of them at first as having much promise. Their faculty was thin and slow. They were put down as among the mediocrities. But while the other class are flagstaffs only, these are trees, going to create themselves like trees by a kind of predestined increment. By and by they are seen to move. Somebody finally speaks of them. Their sentiments are growing bigger, their opinions are getting weight, ideas are breaking in and imaginations are breaking out, and the internal style of their souls, thus lifted, lifts the style of their expression. . . . And finally the wonderful thing about them is that they keep on growing, confounding all expectation, getting all the while more richness and breadth, and covering in all their life, even to its close, with a certain evergreen freshness that is admirable and beautiful to behold.'

We can all supply from our observation instances of this great and beautiful law of Soulgrowth. There are some signal instances among this company to-day. Looking back at our college days, we can all remember cases of men who were expected in those far-off days to do wonderful things in life. But they have not done so. Instead of fulfilling expectation, they have gone backward rather than forward. There are other instances of men who were not suspected in those days of concealing hidden talents beneath 
their very modest countenances, who have gradually moved to the front, and who now hold a high place in the world of scholarship, thought, or pulpit power. They have shown this instinct or talent for growth, and they are where they are, and are doing what they are doing, in virtue of it.

I would not have ventured to bring this matter before you but for one aspect of Bushnell's treatment of the question from which I cordially disagree, and which by rousing a sense of strong antagonism in me has set me thinking on lines that have made me feel, there is a matter that can be usefully handled here to-day. For Bushnell seems to imagine that this talent of growth is not only congenital-which every talent of course is to a large extent-but that it acts in an automatic way beyond the control of its possessor; in other words, that it is a fixed quantity, that one man has it and another has it not, and that there the matter ends. He likens it to an egg which grows briskly in a free state, but 'enlarges never by a line after it has found maturity in a shell.' I. venture to think, on the other hand, that the talent of growth is one that, like every other, can be improved; and that the question whether a man shall grow at all, and the rate at which he may grow, and the limits of his growth, are very largely under his own control. We cannot all grow at the same rate, but we can all go on growing; we cannot all attain the same stature, but we can reach our own, which surely is never attained till long after our college days are ended, and which I would like to think need never be reached in this world. For though a man cannot by taking thought add a cubit to his physical height, he surely can do so mentally and spiritually, for in those kingdoms of grace, that stature is not a fixed point but an elastic limit,- 'a flying point of bliss remote.'

The important thing is, What are the laws of this soul-growth in pulpit talent? Are they ascertainable? And if they are, what are they? Let me make a bold venture, and endeavour to suggest a few points for your consideration.

\section{I.}

I am quite sure of my first. It is the law of hearty and unremitting industry. The man who works, in the ministry, and works in the right way, will grow in knowledge, in efficiency, in power, and in influence all his days. About this there can surely be no doubt whatever. And conversely, the penalty of the ministerial idler is that his soul will slowly but surely atrophy and shrivel up within him. As I find in my Emerson, 'He that will not learn in the great school of life, let him creep into his grave, - the game is not worth the candle.'

I am very much afraid that there is a somewhat widespread idea abroad among our people that many of our ministers do not work hard enough, that a good deal of their time is frittered away in a mysterious manner that shows no results. For all I know this charge may in most cases be an ignorant and somewhat ill-natured libel. But I will venture very heartily to affirm that if it is true of any one of us that after leaving college we cease to carry on the habit of earnest and concentrated study, then we do so at the peril of losing our law of increment. This is, as we all know, a very easy thing to do. There is, for instance, 'no time sheet for parsons,' as a layman said to me a little while ago; and the man who has to work without a time sheet must either draw one up, and make his conscience his time-keeper, or he will fall into lax and indolent ways, - with the inevitable result. Unfortunately, there is for the man who is indolent and who is devoid of a vigorous intellectual conscience, plenty of stuff for pulpit use that can be used with apparent impunity. I say apparent, because there is no real impunity for a pulpit plagiarist. Such a man becomes a mere mental parasite, living on the produce of other minds more vital than his own, and, like all parasites, losing one by one those organs and faculties which are the furniture of the soul, till he becomes like the sacculina, a mere characterless bag for intake and expulsion of what ought to be nutriment, but which becomes mere sewage and offal. The only talent which such a preacher is likely to develop is the talent of a mean dexterity in concealing his parasitism under a cloak of apparent erudition. Even this does not avail for long; the plagiarist is sure to be found out sooner or later. People will soon feel a strange lack of meaning and power in his utterances, however specious their eloquence; and he is liable at any moment to be found out consciously by some one in his audience, who suddenly identifies his sources, and then the end is not far. Assuredly, the preacher's first law of growth is this, - that he should think his own thoughts, and make his own sermons. Once our people realize that what we preach is our own stuff-ore drawn from 
many mines it may be, but smelted in the furnace of our own meditation, and beaten on the anvil of our own earnest industry, - they will begin to listen with a new eagerness; while we ourselves will find as we grow older that the work becomes not only easier, and that subjects throng upon us, but that our power of handling them effectively will increase, and that each year will add something to our stature and influence as preachers and thinkers.

\section{II.}

The second law of growth in pulpit power is to live habitually with the great master-minds of our race, and to wrestle with their works as our daily exercise.

There are, as we all know, thinkers who make us think, and there are others who do our thinking for us. It is of the utmost importance for those whose business is to lead others into fruitful ways of thinking and doing to distinguish between these, -and to cleave to the first as we cleave to life itself. They are the only writers that should find a place on the preacher's library, or at least they should occupy the leading and most frequented shelves. They are not the same writers for all, and they are not the same for any of us at all periods of our thinking lives. But we know that some of the world's mighty minds make us incandescent; they rouse, impel, suggest, drive us into fresh fields, fill us with the quickening process of thought for ourselves, and make the task of preaching a joy and a relief instead of a matter of labour and sorrow, and a much beating of the air. It should be a part of our work at college to find out who for us are the men who do this, and it should be the first task of our ministry as students to make ourselves thoroughly acquainted with their books, and to work out for ourselves the leading lines of thought which they suggest. How can a man stagnate, be he in the distracting city or in the paralysing village, if he keeps in touch with the aristocracy of the world of thought, and holds daily converse with one or more of the world's elect souls? He will grow as his interest in them grows; he will catch something of their greatness of manner, something of the distinction of their thought, something of the glory of their style; the so-called limits of his mind will gradually expand, and he too will be a modest member of the company of the immortals. To quote Emerson once more: 'I do not travel to find comfortable, rich and hospitable people, or clear sky, or ingots that cost too much. But if there were a magnet that would point to the countries and houses where are the persons that are intrinsically rich and powerful, I would sell all I have, and put myself on the road to-morrow. . . . We are as elastic as the gas of gunpowder, and a sentence in a book, and a word dropped in conversation sets free our fancy, and instantly our heads are bathed in galaxies, and our feet tread the floor of the pit,'and then he adds suggestively,- ' and we are entitled to these enlargements, and having once passed our bounds, shall never again be quite the miserable pedants we were' (Essay on 'The Uses of Great Men ').

\section{III.}

I venture next to mention another law of growth and expansion for preachers which may seem to some to be a little out of the way, but I have the utmost confidence that it is an invaluable one, and a feasible one for all. I mean that every one of us should have, alongside of one's professional line of study, some side-line of study of one's very own which demands the exercise of the faculty of investigation, or speculation, or inquiry. I hold that every preacher should be an expert in some branch of learning. He should have what the Germans call a Nebenfach, or secondary line of work, with a view to keeping his mind fresh and vigorous, - which, in a word, shall keep him from becoming a mere routine thinker. I am not referring to mere literary hobbies, but some broad fruitful line of study-philosophical, literary, scientific, historical, or what-not-where the art of original research and the gift of independent thinking are called into request and given constant exercise. And, further, this Nebenfach should be in the line of the great moving currents of thought. There are preachers who are authorities on such matters as Egyptian scarabs, or Assyrian shards, or antediluvian pottery, and it does them no harm to burrow thus among the tombs of the past. Yet I think that those whose business is to lead men in the living present should direct their minds to those problems and subjects and outlooks of thought whose issues lie rather in the future than in the past. If I may make a personal reference here, I should like to say that very early in my ministry I gave myself to investigate what was then an almost unexplored 
region,- the relations between the great Theory of Evolution and Religious Thought,- -and I should like to testify to the immense benefit to myself and my ministry of the discipline and hard work this involved. It has drawn a silken thread of interest through the reading and meditation of a quarter of a century of very hard work; it has brought into the thoughts of every day a sense of plot-interest of its own, and it has enabled me to accumulate an immense capital of notes and comments on life itself which has made my work as a preacher a daily delight and joy. This is only one line of thought out of scores of others that might be mentioned as equally useful and fascinating, which would make even the loneliest country pastorate full of abiding interest and stimulus.

\section{IV.}

There are one or two more laws of growth that remain to be considered which indeed are more important than any yet mentioned.

What we have so far been dealing with are laws or instruments of growth which are individual and solitary, and they may easily become snares if followed out exclusively. It will not do for us preachers to soar too high, till we are out of touch with mother earth. Mere book learning will never make us great men, nor will even the company of the immortals quicken our growing faculty to its fullness. Another means of becoming eminent as preachers is to make ourselves one with our people, not in a weak and trivial way, but by identifying ourselves thoroughly with their spiritual interests, individually as well as in the mass. I am persuaded that most preachers who have any gift of reading and thought in them are prone to despise the drudgery, as it is called, of the pastoral office, and isolate themselves too much in their studies. By so doing they are in peril of losing the very thing that they pride themselves most upon-their freshness of mind. What can be more educative and stimulating to a man who has spent four solid hours of the morning in his study wrestling with the abstract problems of life and thought-and none of us ought to spend less than four hours of conscientious study a daythan to leave these airy abstractions and spend the rest of his day among his people, studying them, considering their problems, getting to know their thoughts, noting their idiosyncrasies, and taking a humorous, but always loving, glance at their oddities? Surely there is nothing more full of stimulus than these exercises of one's faculty of observation on the concrete stuff of human nature, and there is nothing that supplies more grist to the preacher's mill than a thoroughly sympathetic study of one's particular congregation. The pastoral office has its sore trials, and its serious troubles; what I am concerned with is pointing out that it is one of the necessary elements in the training of the preacher, and one of the conditions of his mental and spiritual expansion, that he should be in constant touch with as many of the individual members of his church as he can reach without neglecting his other duties. I am sure I am giving the experience of all of you who have done your part as pastors, that, as the years go by, you realize that what you gain through contact with your people is greater, and it may even be of finer quality, than what you have been able to give them. The channels of a man's sympathies are not only broadened but enriched by the contribution of his people's friendship and trust. For if a man's mind is fed by thought, his heart is fed by sympathy. There is a wonderfully quickening and impelling power in this spiritual contact with average struggling men and women, whose silent heroism is entangled so inextricably with their commonplace and meaner qualities. Life, after all (of which the noblest thought is but the shadow or mirror), is the great educator; and we ministers must see to it that we do not foolishly despise the school of homely experience, and the rewarding intercourse of ordinary minds.

\section{V.}

And now for the last, and if I had the grace needful, it would be a best word. The final condition and law of growth as preachers of the word is to cultivate the law of retirement, the law of fellowship with the Unseen; the law of meditation and prayer. It might seem to an outsider a strange thing to hear one preacher urge his brethren not to forget the call to devotion and quiet musing as a daily duty; yet we who are in the circle of knowledge know well how easy it is to be a keeper of other men's vineyards, and yet to neglect one's own! Paradoxical as it may seem, I fear that if there is one danger to which we are practically liable more than another, it is to forget the habit of personal piety. It is the preacher's business and profession to pray constantly for and 
often with others; he is perpetually thinking of and for them, and urging them to the performance of this and that neglected duty. And just as it is his temptation to forget the offertory while always urging others to give, he is prone to forget to pray for himself,-so busy is he praying for others. And so he is apt to fall into fits of accidie and despondency and barrenness of which he is heartily ashamed, but whose cause is not far to seek. I an not without my fears that it is this curse of professionalism-this tendency to handle the high things of the spirit as a matter of routine, - this materialization of the ethereal elements of the soul-life, that accounts for the ossification of so many preachers' powers before they reach middle age, and for the fact that by the time they have attained to life's meridian they have lost most of the stimulating and inspiring gifts they once had in the more vital years of youth.
There is no more prime duty, no more imperative need of us who are preachers of the holy Word of God, than to keep the fire burning brightly in the inner shrine of our own spirits. Those who do so will in time have faces that shine with a radiance that comes from within; their spirits will ripen instead of hardening with the lapse of years; they will grow in grace and in the knowledge of their heavenly Lord; and they will be able to lead others with an ever-deepening trust and love to the throne of the heavenly grace. There are some old ministers whom it is a privilege and a delight to hear in prayer, for as we listen we feel that Heaven is very near these Beulah pilgrims, and that there is but a step between us and seeing the Invisible itself. Here is an ideal which it should be the utmost endeavour of every minister to attain.

\section{Eiterature.}

\section{PRINCIPAL IVERACH.}

THE volume entitled The Christian Message, which Messrs. Hodder \& Stoughton have published ( $7 \mathrm{~s}$. $6 \mathrm{~d}$. net), is an appropriate appendix to the article on Principal James Iverach which was contributed to The Expository Times last month. For it contains the lectures delivered by Dr. Iverach to the students of the United Free College in Aberdeen at the close (and occasionally at the opening) of each session since 1905 .

The variety is very great. It ranges from an exegesis of the phrase 'into my name' to an exposition of the Hegelian theory of the State. And the lecturer is just as much at home with Hegel as with the grammar of New Testament Greek.

The earlier lectures are occupied with the work of the ministry. They are the ripe fruit of a successful pastorate, a sympathetic recognition of the variety of pastors and pastorates, and a healthy, humorous humanity. Dr. Iverach commends wise adaptation: 'But then there are south and north, east and west, and for each we shall have to make a particular study. More particularly we shall have to study the local conditions of the place if we are to know our people. Are we to work in Aberdeen, then it would be well to know the im- portance of the twelve-mile limit, and the characteristics of those who dwell within it.' One can see the smile on the faces of the students as they remembered the popular saying, 'Tak' awa' Aiberdeen and twal mile roun', and faur are ye?'

\section{THE BIBLE AND SOCIAL LIFE.}

Professor Charles Ryder Smith, D.D., has been fortunate in the choice of his subject. He chose it originally as a thesis for the degree of Doctor of Divinity in the University of London. He made good the choice, both in obtaining the degree and in issuing this handsome volume. The title is The Bible Doctrine of Society in its Historical Evolution (T. \& T. Clark; I 8s.).

$\mathrm{He}$ has been fortunate, we say. It is society that is the theme of the most popular writing at the present time, and perhaps also of the most powerful thinking. It is in some form of social salvation that anxious reformers are seeking a solution of the world's unrest. And the most deeply felt need.of all is a basis-a clear basis in Scripturefor the belief that God means to save society; and that the salvation is to be found in our Lord Jesus Christ. That basis Dr. Ryder Smith has provided. That is the meaning of his book. 